\title{
Enzymatic Conversion of Mannan-Rich Plant Waste Biomass into Prebiotic Mannooligosaccharides
}

\author{
Nosipho Hlalukana, Mihle Magengelele (D), Samkelo Malgas * (D) and Brett Ivan Pletschke (D) \\ Enzyme Science Programme (ESP), Department of Biochemistry and Microbiology, Rhodes University, \\ Makhanda 6140, Eastern Cape, South Africa; g13h3281@campus.ru.ac.za (N.H.); \\ g15m4462@campus.ru.ac.za (M.M.); b.pletschke@ru.ac.za (B.I.P.) \\ * Correspondence: samkelo.malgas@up.ac.za; Tel.: +27-12-420-4149
}

Citation: Hlalukana, $\mathrm{N}$.

Magengelele, M.; Malgas, S.;

Pletschke, B.I. Enzymatic Conversion of Mannan-Rich Plant Waste Biomass into Prebiotic Mannooligosaccharides. Foods 2021, 10, 2010. https://doi.org/ 10.3390 / foods10092010

Academic Editors: Alberto Cepeda Sáez and Alejandra Cardelle Cobas

Received: 29 June 2021

Accepted: 22 August 2021

Published: 26 August 2021

Publisher's Note: MDPI stays neutral with regard to jurisdictional claims in published maps and institutional affiliations.

Copyright: (c) 2021 by the authors. Licensee MDPI, Basel, Switzerland. This article is an open access article distributed under the terms and conditions of the Creative Commons Attribution (CC BY) license (https:// creativecommons.org/licenses/by/ $4.0 /)$

\begin{abstract}
A growing demand in novel food products for well-being and preventative medicine has attracted global attention on nutraceutical prebiotics. Various plant agro-processes produce large amounts of residual biomass considered "wastes", which can potentially be used to produce nutraceutical prebiotics, such as manno-oligosaccharides (MOS). MOS can be produced from the degradation of mannan. Mannan has a main backbone consisting of $\beta-1,4$-linked mannose residues (which may be interspersed by glucose residues) with galactose substituents. Endo- $\beta-1,4$-mannanases cleave the mannan backbone at cleavage sites determined by the substitution pattern and thus give rise to different MOS products. These MOS products serve as prebiotics to stimulate various types of intestinal bacteria and cause them to produce fermentation products in different parts of the gastrointestinal tract which benefit the host. This article reviews recent advances in understanding the exploitation of plant residual biomass via the enzymatic production and characterization of MOS, and the influence of MOS on beneficial gut microbiota and their biological effects (i.e., immune modulation and lipidemic effects) as observed on human and animal health.
\end{abstract}

Keywords: endo- $\beta-1,4-$ mannanase; mannan; mannooligosaccharide; gut microbiome; prebiotic; probiotic

\section{Introduction}

Lignocellulosic biomass mainly consists of three polysaccharides (cellulose, hemicelluloses, and pectin) and an aromatic polymer (lignin) [1]. Hemicelluloses account for about 15 to $25 \%$ of all lignocellulose in dry mass basis [2]. In softwood species, legumes and agro-industrial by-products (spent coffee grounds and palm kernel press cake, among others), mannans are the most abundant hemicelluloses [3-5]. The huge amount of residual plant biomass considered as "waste" can potentially be used to produce various valueadded products, such as prebiotics, biofuels, animal feeds, chemicals, enzymes, etc. [6]. It is this biomass which has the potential to be used for enzymatic generation of prebiotic mannooligosaccharides (MOS).

A complex dynamic relationship between the host and the gastrointestinal bacteria (microbiota) occurs shortly after birth [7]. The microbiota diversifies as a function of age to form an intestinal microbiota that is unique for each individual. Several findings suggest that the microbial cohort remains relatively constant once adulthood is reached. However, the composition of the resident microbiota may alter as a result of environmental factors, such as diet and antibiotic usage [8,9]. The gut microbiota intimately interacts with the host's epithelial cells and stromal cells to play several crucial regulatory functions, such as regulating barrier function, maintaining mucosal immune homeostasis and host-microbiota symbiosis, prevention of pathogenic infections, and metabolism regulation [10]. As a result of these crucial roles exhibited by the microbiota, a healthy body is inseparable from an integrated gut to microbiota relationship [11]. Fostering the growth of these microbial species in humans is crucial in disease prevention and therapy. Hemicellulose-derived 
prebiotic oligosaccharides are able to selectively stimulate or inhibit the growth of specific microbial individual species, and this makes them ideal for applications in microbiotalinked disease prevention and therapy [12].

Simply defined, prebiotics are non-digestible food components that selectively stimulate the growth or activity of specific indigenous bacteria (probiotics), such as lactobacilli and Bifidobacterium and non-pathogenic yeast, Saccharomyces boulardii, while inhibiting the growth of toxin-producing bacteria, such as Streptococcus pneumonia, proteolytic Clostridia and Escherichia coli, in the digestive tract, in a manner claimed to be beneficial for the host [12-14]. Prebiotics are primarily carbohydrates (oligosaccharides and polysaccharides) in nature, with oligosaccharides included in this category being fructooligosaccharides (FOS), xylooligosaccharides (XOS), galactooligosaccharides (GOS), mannooligosaccharides (MOS) and pectin oligosaccharides (POS), as well as some sugar alcohols [15,16].

\section{Mannan-Containing Waste Biomass Derived from Agro-Processing}

Pineapples are tropical plants which belong to the family Bromeliaceae [17]. Pineapples are usually eaten as fresh fruit, but some pineapples are processed into fruit juice while others are canned $[17,18]$. The processing of pineapples for the food sector usually results in waste arising from the peel and pulp that is often left to rot on farms or is disposed of in ways that do not benefit the economy [19]. Research has been performed to find ways in which this waste stream can be beneficial to the economy. Pineapple waste has been shown to contain sucrose, as well as starch and hemicellulose [19-21]. These saccharides can be turned into value-added products that can be used to benefit the economy while also decreasing the waste produced and lessening the burden on landfills. One of the ways in which pineapple waste can be used as a value-added product is its use as an animal feed, particularly for monogastric animals [22]. However, the problem with using pineapple waste as an animal feed arises from its low protein content [23]. This is overcome by using sugars found in pineapple waste, especially those in the peel, for growing microorganisms that may be used to increase the protein content of the waste product [24]. This ensures that the animal feed industry is less reliant on traditional sources that have been used as protein for animal feeds [24]. Pineapple waste has also been used as a starting substrate to produce antioxidant products which offer health benefits [17]. Pineapples are among the most widely produced fruits in South Africa, with a total of 115,507 metric tons of pineapple production reported for the period 2018/2019 (https://www+.statista.com/statistics/1155 961/ production-of-pineapples-in-south-africa/, accessed on 16 August 2021).

The global forestry industry produces wood pulp and paper from softwood trees, such as pine, fir, and spruce trees. These softwoods are native to the Northern hemisphere countries, but it has been shown that they can also grow in the Southern hemisphere, however, they take a long time to grow in these regions, where they take anywhere from 20 to 60 years to fully mature [25]. The forestry industry produces a lot of waste, such as sawdust and bark. Biomass waste is projected to be about 2,100,000 metric tons in the 2017 to 2027 period, and this will be from pine and Eucalyptus. Data on the amount of pine waste currently produced in South Africa are difficult to obtain, but it is estimated that about 376,000 tons are produced annually [26]. Softwood derived sawdust hemicelluloses contain galactoglucomannan as the major hemicellulose, followed by arabinoglucuronoxylan, and arabinogalactan, and can be used for several applications in the bioeconomy, such as the production of bioethanol and use as functional foods [3]. The use of sawdust and wood shavings is important in the pharmaceutical industry since they have been reported to show antimicrobial, antioxidant, anti-inflammatory and anti-tumoral activities [27]. These bioactive properties are said to be due to the phenolic compounds in the bark of the pine tree. Sawdust and wood shavings from pine, therefore, have significant potential in the fields of food preservation and nutraceuticals [27].

Aloe plants, which consist of over 360 species known today, have long been known to have medicinal properties, especially in traditional medicine [28]. There is some debate as to which family the aloe plant comes from, as most of the literature suggests that 
it is part of the Liliaceae family, although it has also been said to belonging to a family of its own, Aloaceae [29,30]. Aloe plants are commonly found in dry regions of Africa, Asia, Southern Europe and the Mediterranean region [28]. The medicinal benefits of aloe plants are attributed to the entire leaf, the skin and the gel. The gel portion of the leaf is known to contain polysaccharides composed of monosaccharides such as mannose, glucose, arabinose and galactose [31]. Acetylated mannan, known as acemannan, constitutes approximately $50 \%$ of the polysaccharides found in Aloe vera gel, making it the most abundant polysaccharide in $A$. vera $[32,33]$. Studies on the differences in polysaccharide composition between $A$. vera and $A$. arborescens indicate that the different species contain the same types of polysaccharides, although they are found in different concentrations among the two species [31].

Coffee is the second largest traded commodity after petroleum. In 2014 and 2016, the International Coffee Organization (ICO) estimated that the amount of coffee consumed worldwide was 8.5 and 9.3 billion $\mathrm{kg}$, respectively. Production of coffee results in the generation of spent coffee ground (SCG) which contains lignocellulosic material [34]. South Africa, Angola, Kenya, Uganda and Ethiopia are the major producers of SCG in Africa. SCG is rich in sugars and contains about $45.3 \%$ of them in dry mass basis [35]. Galactomannan, responsible for the high viscosity of coffee extract, is the major polysaccharide in SCG that forms about $20-30 \%$ dry matter and is water-insoluble [36,37]. SCG can be used for generation of various value-added products, such as enzymes [38], MOS [39] and fermentable sugars [5,40].

Palm kernel cake (PKC) is an agro-industrial waste produced from the extraction of palm oil. The worldwide production volume of palm oil increases every year. It has been reported that in the periods 2015 to 2016 and 2018 to 2019, between 7 and 8.55 million metric tons of PKC, respectively, were produced worldwide (https: / /www.statista.com/statistics / 613479/palm-kernel-oil-production-volume-worldwide/, accessed on 11 October 2020). Nigeria, Indonesia, Malaysia and Thailand are the main producers of palm oil in the world [41]. The Singapore-listed agri-business, Wilmar, owns palm oil estates in Uganda and West Africa where palm oil plants are planted on 6000 and 39,000 hectares of land (https://www.wilmar-international.com/, accessed on 11 October 2020). The Societe Financiere des Caoutchoucs (SOCFIN) group owns more than 51,000 hectares in Nigeria, Ivory Coast and Cameroon (https:/ / www.socfin.com/en, accessed on 11 October 2020). The chemical composition of PKC differs based on the type of fruit and the method used for oil extraction. Enzymatic hydrolysis of PKC is important for MOS production since PKC is rich in crude fiber, which mainly consists of cellulose and hemicellulose, where hemicellulose is composed of 58\% linear mannan [18,42]. Because PKC has a high content of crude fiber, PKC is mostly used in feeding ruminants and limited in the non-ruminant diets e.g., poultry. Table 1 below shows the amount of mannan composition found in different biomass wastes generated from various agro-processes.

Table 1. The amount of mannan present in different biomass wastes.

\begin{tabular}{cccc}
\hline Biomass Waste & $\begin{array}{c}\text { Mannan Composition } \\
(\mathbf{( \% ) ,} \text { Dry Mass Basis }\end{array}$ & Type of Mannan & References \\
\hline SCG & 20 & Galactomannan & {$[5,34,40]$} \\
PKC & 60 & Linear mannan & {$[43]$} \\
CM & 61 & Linear mannan & {$[44]$} \\
PP & 1.5 & Galactomannan & {$[21]$} \\
PSD (softwoods) & 12 & Acetyl-galactoglucomannan & {$[45,46]$} \\
A. vera & 50 & Acetyl-galactomannan & {$[32]$}
\end{tabular}

The above listed mannan-containing waste streams are usually generated from agricultural processing activities embarked upon in various agricultural and food sectors in various African markets and may serve as rich substrates for the enzymatic generation 
of the nutraceutical prebiotics. The advantage in the exploration of using agricultural crop residues as starting materials for nutraceuticals production is that it paves a way for the manufacturers to substantially reduce the cost of raw materials, as well as solve their disposal problems [47].

\section{Mannan}

Mannans are naturally found in four different forms, namely linear mannan, glucomannan, galactomannan, and galactoglucomannan [48]. Linear mannan is composed of linear chains of D-mannose residues linked by $\beta$-1,4-glycosidic bonds. The resemblance of the linear mannan backbone to cellulose makes it water-insoluble like the latter [49]. Glucomannan, on the other hand, is composed of a combination of D-mannose and Dglucose residues linked by $\beta-1,4$-glycosidic bonds. The M: $\mathrm{G}$ (mannose: glucose) ratio in glucomannans ranges from around 1.5:1 to 4.2:1 [50]. Glucomannans are hydrophilic and, as a result, are highly soluble in water [49]. Galactomannans, on the other hand, are composed of linear chains of D-mannose residues that are substituted by galactose residues via $\alpha$-1,6-glycosidic bonds. The D-mannose/D-galactose substitution ratio of galactomannans differs from one gum to another (with the following ratios for locust bean (4:1), tara gum (3:1), guar gum (2:1) and (1:1) in fenugreek gum) and is responsible for other functional properties as well such as viscosity and gel-forming ability of the gum $[48,49]$. Galactoglucomannans, the most complex of mannans, are composed of a glucomannan backbone with D-galactose substitutions. The mannose, glucose, and galactose residues in galactoglucomannan are reported to be in the molar ratio of 3:1:1. Galactoglucomannans can be acetylated at the C-2 and C-3 positions of mannose residues to various degrees, depending on the source of the polysaccharide [51]. Figure 1 below illustrates the basic structural elements found in four types of mannans which occur in nature.

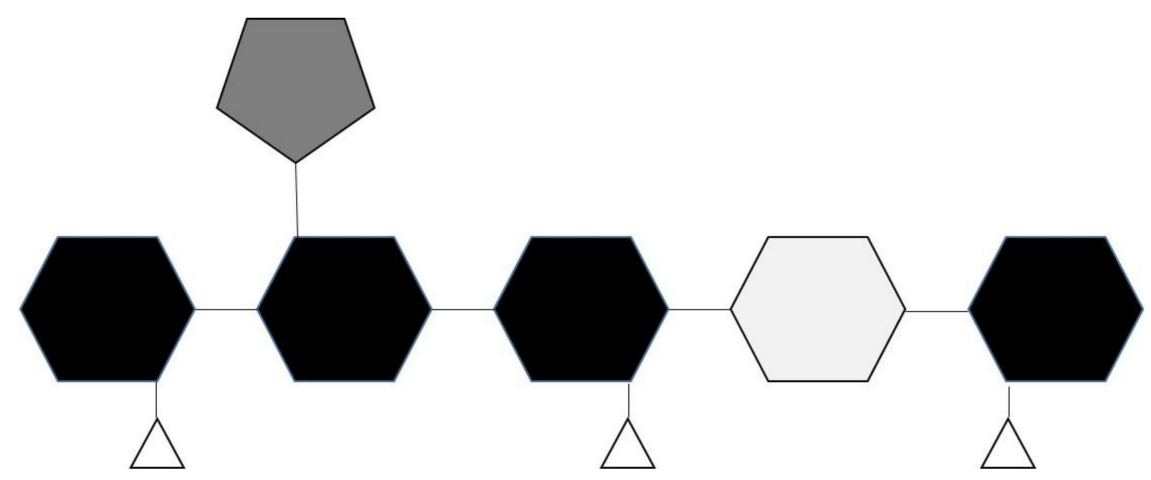

Figure 1. The basic structural components found in mannans. Their backbone is made of $\beta$-1,4-linked mannose residues "black hexagon" which may be randomly interspersed with glucose residues "light grey hexagon", the mannose residues may also contain $\alpha$-1,6-linked galactose sidechains "dark grey pentagon", and acetyl group substitutions at the O-2 and O-3 positions "white triangles".

\section{Endo- $\beta-1,4-M a n n a n a s e s$}

The $\beta$-1,4-D-mannan mannohydrolase (called $\beta$-mannanase, EC 3.2.1.78) is an endoenzyme which is responsible for the random cleavage of $\beta-1,4$-linked internal linkages of the mannan backbone to mainly produce mannobiose and mannotriose, and additional traces of higher oligosaccharides in some instances [52,53]. In the Carbohydrate-Active Enzyme database (CAZY) (https: / / www.cazy.org/, accessed on 11 August 2020), mannanases are allotted to glycosyl hydrolase $(\mathrm{GH})$ clan $\mathrm{A}$, which is characterized by a $(\beta / \alpha)_{8}$-barrel protein fold, under GH families 5, 26, 113 and 134.

Mannanases are often modular, and in addition to catalytic domains, they may also have carbohydrate binding modules (CBM). The role of CBMs is to localize the soluble enzyme to its target substrate, and in some cases, it is also suggested that the CBMs are able to disrupt the structural integrity of the polysaccharide matrix in biomass, making it more accessible to enzymatic hydrolysis [54,55]. 
Most mannanases (GH5, 26 and 113) show a double displacement mechanism with retention of an anomeric configuration. This mechanism involves the attack of a nucleophile at the anomeric center with a general acid-catalyzed displacement of the leaving group. This forms a covalent glycosyl-enzyme acylal intermediate. A general base catalyzed process takes place which involves water attacking the anomeric center of the intermediate, yielding the product and releasing the enzyme to its original state [56]. Only GH5 and 113 mannanases have been reported to exhibit transglycosylation activity, while no such reports have been recorded for GH26 mannanases [57,58].

\section{Enzymatic Production of MOS from Agro-Industrial Biomass}

There are several studies reporting on the hydrolysis of mannans from agro-industrial wastes using mannanases. About $50.7 \%$ of the total mannans from coffee waste were hydrolyzed, producing mannooligosaccharides, using a GH5 mannanase derived from Talaromyces trachyspermus B168 [59]. Also, an Aspergillus niger derived mannanase (Man1) provided the highest increments in soluble solids yield (17\%) from SCG hydrolysis [5]. A recent study showed that $A$. quadrilineatus RSNK-1 derived mannanase was very effective in the degradation of copra meal (CM), yielding 39\% MOS after $1 \mathrm{~h}$ of hydrolysis [60]. Similarly, a Streptomyces sp. BF 3.1 derived mannanase produced $3.83 \mathrm{mg} / \mathrm{mL}$ of reducing sugars, including mannobiose, mannotriose, mannotetraose, mannopentaose, and mannohexaose, during the hydrolysis of $10 \% \mathrm{CM}$ for $5 \mathrm{~h}$ [44]. A total MOS yield of $34.8 \mathrm{~g} / 100 \mathrm{~g}$ dry PKC, indicating $80.6 \%$ hydrolysis of total mannan in PKC, was achieved using a GH5 mannanase derived from Rhizomucor miehei [61]. A study on the hydrolysis of spruce derived galactoglucomannan by two mannanases from Cellvibrio japonicus showed that CjMan5A action resulted in higher amounts of mannotriose and mannotetraose than that of CjMan26A, which mainly generated mannose and mannobiose as end products [62].

\section{Identification and Quantification of Mannanase Produced MOS}

Produced MOS can be identified using a variety of methods which include chromatography and electrophoretic gels. Thin layer chromatography (TLC) is one of the most used methods to determine the degree of polymerization (DP) of produced MOS [63]. TLC uses coated plates as the stationary chromatographic phase for the separation of oligosaccharides of different DP. TLC is a rapid and cheap method of analyzing oligosaccharides [64]. This method uses silica gel, aluminum, or cellulose plates as the stationary phase and uses a solvent as the mobile phase for separation of the MOS. The hydrolysis products are visually observed as spots on the silica plate that have migrated differently based on their size, with the low DP MOS moving along faster and further up the plate. Using TLC also allows for multiple samples to be viewed on one plate for a better comparison of various samples [64]. The use of TLC has been adapted to more sophisticated techniques that allow for better quantification of oligosaccharides. These include high performance-TLC (HPTLC) which is a rapid and cost-effective method that offers a high sensitivity of analysis and produces reproducible results [65]. The use of HPTLC also requires the use of a small amount of sample, which means that MOS produced will not be wasted during their analysis [65]. HPTLC works on the same principle as normal TLC, having a solvent mobile phase that moves along the stationary phase due to capillary action, which helps the analytes that have a lower affinity for the stationary phase to move faster along the plate than those with a higher stationary phase affinity which move slower along with the plate.

Fluorophore-assisted carbohydrate electrophoresis (FACE) is another method that can be used for the visualization of MOS. In FACE, a fluorescent dye is attached to the reducing end of the oligosaccharide and is followed by high resolution viewing on a polyacrylamide slab gel [66]. Polyacrylamide gels require negatively charged molecules to move through the electric field, which is not usually the case for most carbohydrates [66]. This means that carbohydrates that are not charged or those which have a net positive charge need to be tagged with a fluorophore that will give them a net negative charge in order for them to be able to move on the FACE gel $[66,67]$. Some fluorophores used to tag these carbohydrates 
are 8-amino-1,3,6-naphthalenetrisulfonic acid (ANTS) and 8-amino-1,3,6-pyrenetrisulfonic acid (APTS) [67]. The oligosaccharides migrate through the gel based on size, and the abundance of the oligosaccharide being analyzed is measured by the intensity of the band that is represented by it [68].

Structural analysis of MOS can be achieved by using spectroscopic methods, including mass spectrometry (MS), Fourier-transform infrared spectroscopy (FTIR) and 1D/2D nuclear magnetic resonance (NMR) $[32,33,69]$. The structural analysis of MOS can provide more information than that offered by visualization techniques such as FACE and TLC (limited to DP analysis), it offers insights on glycosidic linkages in the MOS (using MS or NMR), the degree and extent of substitution of MOS by substituents such as galactosyl substituents and acetyl groups (using NMR or FTIR), and in some cases the molecular masses of the MOS (using MS) [69-71]. Using 2D NMR, data from ${ }^{13} \mathrm{C}$ NMR can be used to show the presence of a glycosidic bond $(\beta-1,4)$ by the resonance of $C 4$ in reducing $D$ mannose at $81.1 \mathrm{ppm}$, while from ${ }^{1} \mathrm{H}$ NMR spectra the resonances at $5.2 \mathrm{ppm}(\mathrm{MR} \alpha)$ and 4.7 ppm $(\mathrm{MNR} \beta)$ can be assigned to the anomeric protons of the reducing and non-reducing termini of the MOS, respectively [69].

\section{MOS Generation Using Mannanases from Various GH Families}

To date, it is predominantly mannanases from families GH5 and GH26 that have been used in studies to investigate the production of different types of MOS or the analysis of mannanase hydrolysis products patterns using model mannan substrates and/or mannancontaining agricultural residues (Table 2). The yield and product profile of MOS from the hydrolysis of mannans by mannanases varies according to the source or type of the mannan hydrolyzed, the enzyme activity or specificity as well as incubation conditions such as $\mathrm{pH}$, hydrolysis time, the temperature of incubation, etc. Regarding processing conditions (e.g., temperature, $\mathrm{pH}$ and reaction time), bacterial mannanases appeared to be more alkalophilic ( $\mathrm{pH} 6.0$ to 8.0), while fungal mannanases were acidophilic ( $\mathrm{pH} 4.0$ to 6.0) (Table 2). Generally, mannanases display optimal activity at a temperature range of 30 to $50{ }^{\circ} \mathrm{C}$ and about 12 to $48 \mathrm{~h}$ to produce high quantities of MOS (Table 2). During MOS production, mannanases should ideally have no or lower exo-mannanase ( $\beta$-mannosidase) activity so that mannose production can be minimized in the MOS mixture.

Table 2. Production of MOS by mannanases from various mannan and mannan-containing agricultural residues.

\begin{tabular}{|c|c|c|c|c|c|}
\hline $\begin{array}{l}\text { Enzyme Name and } \\
\text { Source }\end{array}$ & $\begin{array}{l}\text { Mannan } \\
\text { Substrate }\end{array}$ & $\begin{array}{l}\text { Parameters (pH, } \\
{ }^{\circ} \mathrm{C}, \text { Hours) }\end{array}$ & MOS Produced & Analytical Technique & References \\
\hline \multicolumn{6}{|c|}{ GH5 mannanases } \\
\hline $\begin{array}{c}\text { CjMan5A, Cellvibrio } \\
\text { japonicas }\end{array}$ & $\begin{array}{l}\text { GGM } \\
\text { KG } \\
\text { LBG }\end{array}$ & $7,35,24 \mathrm{~h}$ & $\begin{array}{l}\text { GGM: M1-M4 } \\
\text { KG: M1-M4 } \\
\text { LBG: M1-M3 }\end{array}$ & $\begin{array}{l}\text { HPAEC-PAD: Carbopac } \\
\text { PA200 column }\end{array}$ & {$[62]$} \\
\hline $\begin{array}{c}\text { PaMan5A, Podospora } \\
\text { anserine }\end{array}$ & $\begin{array}{l}\text { INM } \\
\text { KG } \\
\text { LBG }\end{array}$ & $5.2,40,0.5 \mathrm{~h}$ & M1-M3 & $\begin{array}{c}\text { HPAEC-PAD: } \\
\text { Carbo-PacPA-1 column }\end{array}$ & {$[72]$} \\
\hline $\begin{array}{c}\text { ManAK, Aspergillus } \\
\text { kawachii IFO } 4308\end{array}$ & $\begin{array}{l}\text { LBG } \\
\text { KG } \\
\text { GG }\end{array}$ & $3.0,60,12 \mathrm{~h}$ & $\begin{array}{c}\text { LBG: M1-M4, M6 } \\
\text { KG: M1-M6 } \\
\text { GG: M1-M4 }\end{array}$ & $\begin{array}{l}\text { TLC, HPLC: TSKgel } \\
\text { PWXL column }\end{array}$ & [73] \\
\hline $\begin{array}{c}\text { HhMan, Hypothenemis } \\
\text { hampei }\end{array}$ & $\begin{array}{l}\text { LBG } \\
\text { GG }\end{array}$ & $5.5,30,24 \mathrm{~h}$ & M1-M4 & TLC & [74] \\
\hline $\begin{array}{c}\text { BlMan5_8, } \\
\text { Bifidobacterium animalis }\end{array}$ & $\begin{array}{l}\text { INM } \\
\text { LBG }\end{array}$ & $\begin{array}{c}6.0,37,0.0083 \mathrm{~h} \\
(30 \mathrm{~s})\end{array}$ & $\begin{array}{l}\text { INM: M3-M5 } \\
\text { LBG: M2-M5 }\end{array}$ & $\begin{array}{l}\text { HPAEC-PAD: CarboPac } \\
\text { PA200 column }\end{array}$ & [71] \\
\hline $\begin{array}{c}\text { mRmMan5A, } \\
\text { Rhizomucor miechei }\end{array}$ & PKC & $4.5,50,8 \mathrm{~h}$ & M1-M4 & $\begin{array}{l}\text { HPLC-ELSD, Sugar } \\
\text { KS-802 column }\end{array}$ & [61] \\
\hline $\begin{array}{c}\text { TtMan5A, Talaromyces } \\
\text { trachyspermus B168 }\end{array}$ & DCW & $4.5,50,69 \mathrm{~h}$ & M1-M4 & HPAEC-PAD DX-500 & {$[59]$} \\
\hline
\end{tabular}


Table 2. Cont.

\begin{tabular}{|c|c|c|c|c|c|}
\hline $\begin{array}{l}\text { Enzyme Name and } \\
\text { Source }\end{array}$ & $\begin{array}{l}\text { Mannan } \\
\text { Substrate }\end{array}$ & $\begin{array}{l}\text { Parameters }(\mathrm{pH}, \\
\left.{ }^{\circ} \mathrm{C}, \text { Hours }\right)\end{array}$ & MOS Produced & Analytical Technique & References \\
\hline $\begin{array}{c}\text { Bpman5, Bacillus pumilus } \\
\text { CBSW19 }\end{array}$ & LBG & $6.5,50,24 \mathrm{~h}$ & M1-M3, M5, M6 & $\begin{array}{l}\text { TLC, HPLC: C18 reverse } \\
\text { phase column }\end{array}$ & [75] \\
\hline \multirow{2}{*}{$\begin{array}{c}\text { ManF3, Aspergillus niger } \\
\text { BCC4525 }\end{array}$} & $\begin{array}{l}\text { CM } \\
\text { PKC }\end{array}$ & $5.5,50,24 \mathrm{~h}$ & $\begin{array}{l}\text { CM: M1-M5 } \\
\text { PKC: M1-M3 }\end{array}$ & TLC & [76] \\
\hline & Mannan & $5.5,50,0.17-3 \mathrm{~h}$ & $\begin{array}{l}0.17 \text { h: M2-M5 } \\
3 \text { h: M2-M7 }\end{array}$ & HPAEC-PAD & [77] \\
\hline $\begin{array}{c}\text { ManPN11, Bacillus } \\
\text { nealsonii PN-11 }\end{array}$ & LBG & $8.8,55,6 \mathrm{~h}$ & M1-M5, >M5 & $\begin{array}{l}\text { HPAEC: CarboPac } \\
\text { PA100 column }\end{array}$ & [78] \\
\hline $\begin{array}{l}\text { ManPN11, Bacillus } \\
\text { nealsonii PN-11 }\end{array}$ & $\mathrm{CB}$ & $8.8,37,24 \mathrm{~h}$ & M1-M5 & $\begin{array}{l}\text { TLC, HPLC: Aminex } \\
\text { HPX-87P column }\end{array}$ & [79] \\
\hline $\begin{array}{c}\text { Man5HJ14, Bacillus sp. } \\
\text { HJ14 }\end{array}$ & $\begin{array}{l}\text { LBG } \\
\text { PKC }\end{array}$ & $6.5,60,10 \mathrm{~h}$ & $\begin{array}{l}\text { LBG: M1-M7 } \\
\text { PKC: M1-M4 }\end{array}$ & TLC, ESI-MS & [80] \\
\hline \multicolumn{6}{|c|}{ GH26 mannanases } \\
\hline $\begin{array}{c}\text { PaMan26A, Podospora } \\
\text { anserine }\end{array}$ & $\begin{array}{l}\text { INM } \\
\text { KG } \\
\text { LBG }\end{array}$ & $5.2,40,0.5 \mathrm{~h}$ & M1-M4 & $\begin{array}{c}\text { HPAEC-PAD: } \\
\text { Carbo-PacPA-1 column }\end{array}$ & [72] \\
\hline $\begin{array}{c}\text { BoMan26B, Bacteroides } \\
\text { ovatus }\end{array}$ & $\begin{array}{l}\text { GG } \\
\mathrm{LBG}\end{array}$ & $6.5,37,24 \mathrm{~h}$ & $\begin{array}{l}\text { GG: M1-M6 } \\
\text { LBG: M1-M6 }\end{array}$ & $\begin{array}{c}\text { HPAEC-PAD: CarboPac } \\
\text { PA200 and PA20 } \\
\text { columns }\end{array}$ & [81] \\
\hline $\begin{array}{c}\text { CjMan26A, Cellvibrio } \\
\text { japonicas }\end{array}$ & $\begin{array}{l}\text { GGM } \\
\text { KG } \\
\text { LBG }\end{array}$ & $7.0,37,24 \mathrm{~h}$ & $\begin{array}{l}\text { GGM: M1-M4 } \\
\text { KG: M1-M3 } \\
\text { LBG: M1, M2 }\end{array}$ & $\begin{array}{l}\text { HPAEC-PAD: CarboPac } \\
\text { PA200 column }\end{array}$ & {$[62]$} \\
\hline $\begin{array}{c}\text { Mannanase, Bacillus } \\
\text { circulans }\end{array}$ & LBG & $6.0,50,24 \mathrm{~h}$ & M2-M6 & $\begin{array}{l}\text { HPLC: Aminex-HPX42C } \\
\text { column }\end{array}$ & [82] \\
\hline $\begin{array}{c}\text { BoMan26B, Bacteroides } \\
\text { ovatus }\end{array}$ & $\begin{array}{l}\text { GG } \\
\text { INM } \\
\text { LBG }\end{array}$ & $6.5,37,24 \mathrm{~h}$ & $\begin{array}{l}\text { GG: M2-M6, >M6 } \\
\text { INM: M2 } \\
\text { LBG: M2-M6, >M6 }\end{array}$ & $\begin{array}{l}\text { HPAEC-PAD: CarboPac } \\
\text { PA200 column }\end{array}$ & [83] \\
\hline $\begin{array}{c}\text { ManAJB13, } \\
\text { Sphingomonas sp. JB13 }\end{array}$ & $\begin{array}{l}\mathrm{LBG} \\
\mathrm{PKC}\end{array}$ & $6.5,37,10 \mathrm{~h}$ & $\begin{array}{l}\text { LBG: M1-M6 } \\
\text { PKC: M1-M4 }\end{array}$ & TLC, ESI-MS & [80] \\
\hline \multicolumn{6}{|c|}{ GH26 mannobiohydrolases } \\
\hline $\begin{array}{c}\text { BoMan26A, Bacteroides } \\
\text { ovatus }\end{array}$ & $\begin{array}{l}\text { GG } \\
\text { INM } \\
\text { LBG }\end{array}$ & $6.5,37,24 \mathrm{~h}$ & $\begin{array}{l}\text { GG: M2, GM3, M5 } \\
\text { INM: M2 } \\
\text { LBG: M2, GM3 }\end{array}$ & $\begin{array}{l}\text { HPAEC-PAD: CarboPac } \\
\text { PA200 column }\end{array}$ & [83] \\
\hline $\begin{array}{c}\text { CjMan26C, Cellvibrio } \\
\text { japonicas }\end{array}$ & $\begin{array}{l}\text { INM } \\
\text { LBG }\end{array}$ & $37,7.0,0.5 \mathrm{~h}$ & $\begin{array}{c}\text { INM: M2 } \\
\text { LBG: M2, GM2 }\end{array}$ & $\begin{array}{l}\text { HPLC: CarboPac PA100 } \\
\text { column }\end{array}$ & [84] \\
\hline $\begin{array}{c}\text { RSMan26H, } \\
\text { Reticulitermes speratus }\end{array}$ & INM & $5.5,30,1 \mathrm{~h}$ & M2-M5 & $\begin{array}{l}\text { HPLC: Shodex Asahipak } \\
\text { NH2P-50 4E column }\end{array}$ & [85] \\
\hline \multicolumn{6}{|c|}{ GH113 mannanases } \\
\hline $\begin{array}{c}\text { AaManA, Alicyclobacillus } \\
\text { acidocaldarius }\end{array}$ & $\begin{array}{l}\text { KG } \\
\text { LBG }\end{array}$ & $5.5,65,3 \mathrm{~h}$ & $\begin{array}{c}\text { KG: M1-M6 } \\
\text { LBG: M1-M6, >M6 }\end{array}$ & TLC & [86] \\
\hline $\begin{array}{c}\text { BaMan113A, Bacillus sp. } \\
\text { N16- } 5\end{array}$ & $\begin{array}{l}\text { KG } \\
\text { LBG }\end{array}$ & $7.0,30,2 \mathrm{~h}$ & $\begin{array}{c}\text { KG: M1 } \\
\text { LBG: G, GM, GM2, } \\
\text { M1, M2, M4 }\end{array}$ & TLC & [87] \\
\hline \multicolumn{6}{|c|}{ GH134 mannanases } \\
\hline $\begin{array}{c}\text { AnMan134A, Aspergillus } \\
\text { nidulans }\end{array}$ & $\begin{array}{l}\text { INM } \\
\text { KG } \\
\text { LBG }\end{array}$ & $6.0,37,0.25 \mathrm{~h}$ & $\begin{array}{c}\text { INM: M2-M4 } \\
\text { KG: M2-M6, >M6 } \\
\text { LBG: M2-M6, >M6 }\end{array}$ & $\begin{array}{l}\text { TLC, MALDI-TOF-MS, } \\
\text { HPLC: Shim-pack } \\
\text { ISA-07/S2504 column }\end{array}$ & [88] \\
\hline
\end{tabular}


Table 2. Cont.

\begin{tabular}{|c|c|c|c|c|c|}
\hline $\begin{array}{c}\text { Enzyme Name and } \\
\text { Source }\end{array}$ & $\begin{array}{l}\text { Mannan } \\
\text { Substrate }\end{array}$ & $\begin{array}{c}\text { Parameters (pH, } \\
{ }^{\circ} \mathrm{C}, \text { Hours) }\end{array}$ & MOS Produced & Analytical Technique & References \\
\hline \multicolumn{6}{|c|}{ Unidentified mannanases } \\
\hline $\begin{array}{c}\text { Mannanase, Bacillus sp. } \\
\text { GA2(1) }\end{array}$ & SCG & $6.0,50,5 \mathrm{~h}$ & M2, M3 & TLC & [34] \\
\hline $\begin{array}{c}\text { ManAo, Aspergillus } \\
\text { oryzae }\end{array}$ & $\begin{array}{c}\text { GG } \\
\text { KG } \\
\text { LBG }\end{array}$ & $5.0,60,24 \mathrm{~h}$ & $\begin{array}{c}\text { GG: M1-M4, >M4 } \\
\text { KG: M1, M2 } \\
\text { LBG: M1-M3, >M4 }\end{array}$ & FACE & [89] \\
\hline $\begin{array}{c}\text { ManAo, Aspergillus } \\
\text { oryzae }\end{array}$ & $\begin{array}{c}\text { CM } \\
\text { GG } \\
\text { KG } \\
\text { LBG } \\
\text { PKC }\end{array}$ & $5.0,50,12 \mathrm{~h}$ & $\begin{array}{l}\text { CM: M1-M3 } \\
\text { GG: M1-M3 } \\
\text { KG: M1-M4 } \\
\text { LBG: M1-M3 } \\
\text { PKC: M1-M3 }\end{array}$ & $\begin{array}{l}\text { HPLC: Sugar-Pak } \\
\text { column, 2D NMR }\end{array}$ & [90] \\
\hline $\begin{array}{c}\text { rHhMan, Hypothenemus } \\
\text { hampei }\end{array}$ & $\begin{array}{l}\text { GG } \\
\text { LBG }\end{array}$ & $5.5,30,24 \mathrm{~h}$ & M1-M4 & TLC & [74] \\
\hline $\begin{array}{c}\text { Mannanase, Streptomyces } \\
\text { cyaenus }\end{array}$ & PKC & $6.0,37,8 \mathrm{~h}$ & M2-M6 & $\begin{array}{l}\text { TLC, HPLC: Zorbax } \\
\text { carbohydrate column }\end{array}$ & [91] \\
\hline $\begin{array}{c}\text { Mannanase, } \\
\text { Kitasatospora sp. } \\
\text { KY576672 }\end{array}$ & SPF & $6.0,40,32 \mathrm{~h}$ & M1-M6 & $\begin{array}{l}\text { TLC, HPLC: Hi-PlexCa } \\
\text { (Duo) column }\end{array}$ & [92] \\
\hline $\begin{array}{l}\text { Mannanase, } \\
\text { Kitasatospora sp. }\end{array}$ & $\begin{array}{l}\text { INM } \\
\text { LBG } \\
\text { PP } \\
\text { SPF }\end{array}$ & $6.0,40,2-6 \mathrm{~h}$ & $\begin{array}{c}\text { INM: M1-M5 } \\
\text { LBG: M1-M6, >M6 } \\
\text { PP: M1-M6, >M6 } \\
\text { SPF: M1, M2, >M6 }\end{array}$ & TLC & [93] \\
\hline $\begin{array}{l}\text { Mannanase, Penicillium } \\
\text { aculeatum AP S1 }\end{array}$ & $\begin{array}{l}\text { GG } \\
\text { KG } \\
\text { LBG }\end{array}$ & $5.3,50,3 \mathrm{~h}$ & $\begin{array}{c}\text { GG: M1-M3, >M4 } \\
\text { KG \& LBG: } \\
\text { M1-M4, >M4 }\end{array}$ & $\begin{array}{c}\text { TLC, HPLC: } \\
\text { Hamilton RCX-30 } \\
\text { column }\end{array}$ & [94] \\
\hline
\end{tabular}

Substrates: CB-coffee beans, CM-copra meal, DCW-dried coffee waste, GG-guar gum, GGM-galactoglucomannan, INM-ivory nut mannan, KG-konjac glucomannan, LBG-locust bean gum, PKC-palm kernel cake, PKM-palm kernel meal, PP-porang potato, SCG-spent coffee grounds, SPF-sugar palm fruit. Standards: G-galactose, GM-galactosyl-mannose, GM2-galactosyl-mannobiose, GM3-galactosylmannotriose, M1-mannose, M2-mannobiose, M3-mannotriose, M4-mannotetraose, M5-mannopentaose, M6-mannohexaose. Analytical techniques: FACE-fluorescence assisted carbohydrate electrophoresis, ESI-MS-electrospray ionization mass spectrometry, HPLC-highperformance liquid chromatography, HPAEC-PAD-high-performance anion-exchange chromatography with pulsed amperometric detection, MALDI-TOF-MS-matrix-assisted laser desorption/ionization time-of-flight mass spectrometry, NMR-nuclear magnetic resonance spectroscopy, TLC-thin layer chromatography.

The most common MOS produced by enzymatic hydrolysis from mannans seem to be mannobiose (M2), mannotriose (M3) and mannotetraose (M4) (Table 2). Notably, GH5 mannanases did not produce higher DP MOS compared to those produced by GH26 mannanases even though this family of mannanases is reported to display transglycosylation activity. Subtle differences in MOS production have been observed in isoforms (same GH family) of the same enzyme from different species, for example, Man5HJ14 from Bacillus sp. HJ14 releases M1-M7 from LBG, while Bpman5 from Bacillus pumilus CBSW19 releases M1-M3, M5, M6 from the same substrate. Secondly, differences in MOS production have been observed in mannanolytic enzymes from different $\mathrm{GH}$ families and $\mathrm{EC}$ classifications from the same organism, for example, C. japonicas derived CjMan5A, CjMan26A and CjMan26C release different products from LBG, M1-M3; M1-M4; and M2, GM2, respectively. Also, Bacteroides ovatus derived BoMan26A and BoMan26B also release different products from LBG hydrolysis, M2, GM3; and M1-M6, respectively.

\section{Properties and Biological Action of MOS}

As described previously, MOS are short-chain carbohydrates responsible for enhancing the growth of beneficial bacteria while inhibiting the growth of pathogenic bacteria in the digestive tract of mammals. Chacher et al. [95] reported that MOS achieve this effect 
by binding to the type- 1 fimbriae of gram-negative bacteria. Type- 1 fimbriae contain mannose-specific lectins which have a high affinity for mannose residues. Binding of MOS to gram-negative bacteria then prevents these bacteria from attaching to the intestinal mucosa. This causes these bacteria to pass through the intestines, leading to a decrease in these gram-negative bacteria. In the intestine, MOS also increase the production of goblet cells situated in the membrane of the villi $[95,96]$. Goblet cells are well known for secreting mucus, which protects the mucous membranes. These cells also produce glycoproteins called mucins. Mucins contain mannosyl receptors and use these receptors to bind to type 1 fimbriae of gram-negative bacteria, assisting in the decrease of these bacteria in the digestive tract $[95,96]$.

The utilization of MOS by beneficial bacteria such as Lactobacillus sp. and Bifidobacteria sp. results in the production of short-chain fatty acids (SCFA) and lactic acid (LA), which results in the decrease of the $\mathrm{pH}$ in the intestine preventing the attachment of pathogens such as Escherichia coli and Clostridium perfringens to the intestinal mucosa [39,95]. The decrease of these gram-negative bacteria then favors the growth of beneficial bacteria such as Lactobacillus sp. and Bifidobacteria sp. Asano et al. [39] demonstrated that the intake of $1 \mathrm{~g} /$ day and $3 \mathrm{~g} /$ day of MOS increases the content of Bifidobacterium. The content was slightly different, with more bacterium content in $3 \mathrm{~g} /$ day but the difference was not significant. Recently, it has been shown that mannobiose and mannotriose are the preferred oligosaccharides among the probiotic Lactobacillus sp., rather than functional oligosaccharides with higher degrees of polymerization [80]. As shown in Figure 2 below, the decrease of pathogens and the increase of beneficial bacteria results in the decrease of crypt depth and the increase in the height of the villi.

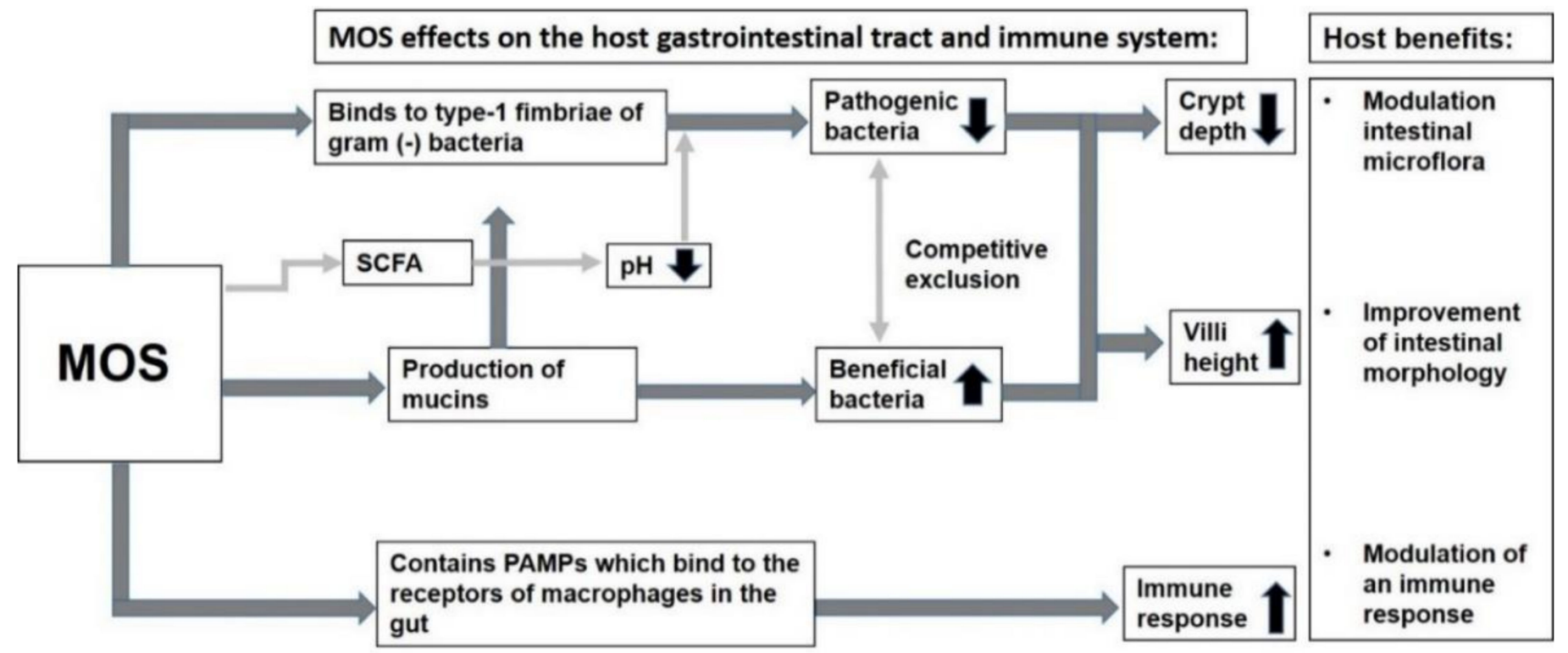

Figure 2. Mechanism of action of MOS. The diagram shows how MOS modulate the intestinal microflora, improve the intestinal morphology and elicit an immune response. The black arrows pointing upwards mean an "increase" in response, while the arrows pointing downwards mean a "decrease" in response.

Intake of MOS triggers an immune response by using pathogen-associated molecular patterns (PAMP) to bind to the PAMP receptors of gut-associated lymphoid tissue (GALT) macrophages [95]. Oligosaccharides with a DP that is greater than six have been reported to be effective at influencing the immune response [97]. MOS cause an increase in the plasma levels of immunoglobulin G (IgG) and IgA in poultry [98]. MOS may probably have the ability to elicit powerful antigenic properties. The intake of MOS also results in the production of the mannose-binding protein by the liver. This protein plays an important role in first-line host defense [98]. Mannose-binding proteins move through the plasma as complexes attached to mannan-binding lectin serine protease 1 (MASP-1) and MASP- 
2 [99]. These complexes bind to the type- 1 fimbriae situated on the surfaces of pathogens. MASPs are also involved in the lectin pathway of the complement system whereby they are responsible for the cleavage of complement protein C4 and C2 into fragments to form C3-convertase which is responsible for eventuating opsonization of particles, the release of inflammatory peptides and lysis of dying host cells [99].

Antioxidants are required to prevent and delay the binding of oxidants to cellular molecules such as DNA and proteins leading to adverse effects on the body such as cardiovascular diseases, liver diseases, diabetes, ageing, skin diseases, etc. [100]. Antioxidants achieve this by donating a hydroxyl group to the radical group on oxidants. The antioxidant activity of MOS can be determined by their ability to scavenge free radicals in their environment [101]. The presence of free radicals is associated with an increase in pathogenicity of certain diseases, caused by increased oxidative stress on the body, therefore, MOS with antioxidant ability would be beneficial in overcoming the effects that these diseases have on the host [101,102]. Lipid oxidation in foods can also lead to rapid food spoilage, which would result in the food having undesirable flavors and odors [103]. Studies conducted on the antioxidant activity of MOS include their ability to scavenge 2,2-diphenyl-1-picrylhydrazyl (DPPH), 2,2'-azinobis (3-ethylbenzothiazoline-6-sulfonic acid) (ABTS+•) and hydroxyl radicals [90,102]. Jana and Kango [90] conducted radical scavenging assays for MOS generated from mannan substrates with different substitution patterns which resulted in different MOS profiles. Their study found that palm kennel cake had more ABTS+ $\bullet$ radical scavenging ability compared to other MOS evaluated, but there was a general stable scavenging ability across all the evaluated MOS for the DPPH.

Lipidemic effects of oligosaccharides have been evaluated for fructooligosaccharides (FOS) and some inulin prebiotics $[104,105]$. These studies have found that supplementing diets with prebiotics had an influence on lipid metabolism where rats showed a decrease in cholesterol levels after being fed FOS [104]. A proposed lipid-lowering mechanism is that fermentation of prebiotics in the gut results in increased fermentation products which then trigger hepatic cholesterol synthesis. It is likely that the fermentation of MOS in the gut may also result in these fermentation products which may trigger hepatic cholesterol synthesis which would, in turn, affect lipid metabolism.

Lee and co-workers reported that coffee (which is generally rich in mannans) consumption, especially by men, has the ability to reduce obesity [106]. Reduction of obesity as a result of coffee consumption is suspected to be due to the presence of bioactive compounds, such as chlorogenic acid, trigonelline, and caffeine [106]. Obesity is a serious health problem that can lead to diseases such as heart disease and diabetes. Many other studies have also reported that coffee also decreases the risk of type 2 diabetes and cardiovascular diseases $[107,108]$. Coffee extract treatment of adipose cells, 3T3-L1, showed that coffee disrupts their cell cycle by preventing it from continuing into the G2/M phase [107]. Coffee also results in the degradation of the molecule involved in insulin signaling, insulin receptor substrate 1 (IRS1) [107]. The molecular mechanism of how coffee intake reduces the risk of different diseases is still unclear, because previous reports are observational [107].

A few studies have also implicated MOS in eliciting anti-cancer bioactivity. MOS obtained from palm kernel cake and copra meal reduced the viability of a human colon cancer cell line, Caco-2, by $74.19 \%$, and $62.21 \%$, respectively [90]. Ghosh and co-workers [109] also demonstrated that MOS obtained from copra meal hydrolysis have the ability to reduce survival of the human colon cancer cell line, HT-29, by 50\%, while guar gum reduced Caco-2 cell line survival by $30.95 \%$.

Recently, a study showed that a yogurt containing a symbiotic concoction composed of konjac glucomannan derived oligosaccharides (KMOS) and Bifidobacterium animalis ssp. lactis BB12 (BB12) improved black fecal weight and number and gastrointestinal transit rate of diphenoxylate-induced constipated Kunming mice [110]. Additionally, restoration of intestinal damage, secretion of excitability neurotransmitters, and expression of components of the SCF/c-Kit pathway were also notably enhanced in mice administered with yogurt containing KMOS and/or BB12 [110]. 
SCFAs, such as acetate, generated during prebiotics fermentation by microorganisms may have a detrimental effect on the lipid profile [107]. Recommended prebiotic dosage is between 1.5 to $5 \mathrm{~g}$ /day, overdose of prebiotics may lead to side effects, such as osmotic diarrhoea and flatulence $[107,108]$. Rapid fermentation of carbohydrates also leads to intestinal bloating and excessive gas formation, leading to abdominal pain [109]. The adverse and beneficial effects of prebiotics vary between individuals and are influenced by intestinal oligosaccharide fermentation [109].

\section{Conclusions}

This review highlights recent advances made in enzyme technology for the production of prebiotic MOS from mannan-containing lignocellulosic wastes generated from various agro-processes applied in the African agricultural sector. The structural diversity of mannanase produced MOS depends on the type of substrate, pretreatment and structure/function of the mannanase utilized. Most of the mannanases utilized for MOS production to date belong to GH5 and GH26, GH26 being more tolerant in utilizing the decorated galactomannans as a substrate, while the GH5 mannanases are more restrictive in binding decorated mannans in their active sites and may also exhibit undesirable transglycosylation activity during MOS production alongside GH113 mannanases. A growing body of knowledge on the diverse specificity of various GH family mannanases at a structural level and utilization of mannans derived from different agricultural residues is anticipated to bolster improvements in the yields of MOS produced, as well as in a higher diversity in the MOS produced.

Further investigations are required to deeply elucidate the mechanisms involved in the biological effects demonstrated by MOS, particularly their immune modulation and lipidemic effects on humans and animals. It still remains elusive as to which is the ideal composition of the gut microbiota and whether MOS can induce the ideal range of gut microbiota. It's also still unclear as to what the appropriate dose of these dietary modulators would be for improving health. In addition, the knowledge on the safety of prebiotics is still in its infancy, over time they may very well contribute to antibiotic resistance and prevent gastrointestinal disorders.

Author Contributions: Conceptualization, S.M. and B.I.P.; literature data collection, N.H., M.M., and S.M.; writing — original draft preparation, N.H., M.M., and S.M.; writing—review and editing, S.M. and B.I.P.; supervision, S.M. and B.I.P.; project administration, S.M.; funding acquisition, B.I.P. All authors have read and agreed to the published version of the manuscript.

Funding: This research was funded by the National Research Foundation of South Africa (NRF), CPRR Grant UID 113312, and the APC was funded by the Research Office at Rhodes University.

Institutional Review Board Statement: Not applicable.

Informed Consent Statement: Not applicable.

Data Availability Statement: No new data were created. Data sharing not applicable.

Conflicts of Interest: The authors declare no conflict of interest.

\section{References}

1. Van Dyk, J.S.; Pletschke, B.I. A review of lignocellulose bioconversion using enzymatic hydrolysis and synergistic cooperation between enzymes-Factors affecting enzymes, conversion and synergy. Biotechnol. Adv. 2012, 30, 1458-1480. [CrossRef]

2. Malgas, S.; Chandra, R.; Van Dyk, J.S.; Saddler, J.N.; Pletschke, B.I. Formulation of an optimized synergistic enzyme cocktail, HoloMix, for effective degradation of various pre-treated hardwoods. Bioresour. Technol. 2017, 245, 52-65. [CrossRef]

3. Willför, S.; Sundberg, K.; Tenkanen, M.; Holmbom, B. Spruce-derived mannans-A potential raw material for hydrocolloids and novel advanced natural materials. Carbohydr. Polym. 2008, 72, 197-210. [CrossRef]

4. Cerveró, J.M.; Skovgaard, P.A.; Felby, C.; Sørensen, H.R.; Jørgensen, H. Enzymatic hydrolysis and fermentation of palm kernel press cake for production of bioethanol. Enzym. Microb. Technol. 2010, 46, 177-184. [CrossRef]

5. Jooste, T.; García-Aparicio, M.P.; Brienzo, M.; Van Zyl, W.H.; Görgens, J.F. Enzymatic hydrolysis of spent coffee ground. Appl. Biochem. Biotechnol. 2013, 169, 2248-2262. [CrossRef] 
6. Chapla, D.; Pandit, P.; Shah, A. Production of xylooligosaccharides from corncob xylan by fungal xylanase and their utilization by probiotics. Bioresour. Technol. 2012, 115, 215-221. [CrossRef] [PubMed]

7. Guarner, F.; Malagelada, J. Gut flora in health and disease. Lancet 2003, 360, 512-519. [CrossRef]

8. Burokas, A.; Arboleya, S.; Moloney, R.D.; Peterson, V.L.; Murphy, K.; Clarke, G.; Stanton, C.; Dinan, T.G.; Cryan, J.F. Targeting the microbiota-gut-brain Axis: Prebiotics have anxiolytic and antidepressant-like effects and reverse the impact of chronic stress in mice. Biol. Psychiatry 2016, 82, 472-487. [CrossRef]

9. Bruce-keller, A.J.; Salbaum, J.M.; Berthoud, H. Harnessing Gut Microbes for Mental Health: Getting From Here to There. Intest. Microbiota Ment. Health 2018, 214-223. [CrossRef]

10. Weina, L.; Yu, D.; Qian, C.; Peng, Z. Gut microbiome and cancer immunotherapy. Cancer Lett. 2019, 447, 41-47.

11. Hekmatshoar, Y.; Rahbar Saadat, Y.; Hosseiniyan Khatibi, S.M.; Ozkan, T.; Zununi Vahed, F.; Nariman-Saleh-Fam, Z.; Pourghassem Gargari, B.; Sunguroglu, A.; Zununi Vahed, S. The impact of tumor and gut microbiotas on cancer therapy: Beneficial or detrimental? Life Sci. 2019, 233, 116680. [CrossRef] [PubMed]

12. Yasmin, A.; Butt, M.S.; Afzaal, M.; van Baak, M.; Nadeem, M.T.; Shahid, M.Z. Prebiotics, gut microbiota and metabolic risks: Unveiling the relationship. J. Funct. Foods 2015, 17, 189-201. [CrossRef]

13. Vandenplas, Y. Probiotics and prebiotics in infectious gastroenteritis. Best Pract. Res. Clin. Gastroenterol. 2016, 30, 49-53. [CrossRef] [PubMed]

14. Charoensiddhi, S.; Conlon, M.A.; Franco, C.M.M.; Zhang, W. The development of seaweed-derived bioactive compounds for use as prebiotics and nutraceuticals using enzyme technologies. Trends Food Sci. Technol. 2017, 70, 20-33. [CrossRef]

15. Hutkins, R.W.; Krumbeck, J.A.; Bindels, L.B.; Cani, P.D.; Fahey, G.; Goh, Y.J.; Hamaker, B.; Martens, E.C.; Mills, D.A.; Rastal, R.A.; et al. Prebiotics: Why definitions matter. Curr. Opin. Biotechnol. 2016, 37, 1-7. [CrossRef] [PubMed]

16. Moreno, F.J.; Corzo, N.; Montilla, A.; Villamiel, M.; Olano, A. Current state and latest advances in the concept, production and functionality of prebiotic oligosaccharides. Curr. Opin. Food Sci. 2017, 13, 50-55. [CrossRef]

17. Saravanan, P.; Muthuvelayudham, R.; Viruthagiri, T. Enhanced production of cellulase from pineapple waste by responses surface methodology. J. Eng. 2013, 2013. [CrossRef]

18. Daud, Z.; Hatta, M.Z.M.; Kassim, A.S.M.; Awang, H.; Aripin, A.M. Exploring of agro waste (pineapple leaf, corn stalk, and napier grass) by chemical composition and morphological study. BioResources 2014, 9, 872-880. [CrossRef]

19. Tanaka, K.; Hilary, Z.D.; Ishizaki, A. Investigation of the utility of pineapple juice and pineapple waste material as low-cost substrate for ethanol fermentation by Zymomonas mobilis. J. Biosci. Bioeng. 1999, 87, 642-646. [CrossRef]

20. Olver, B.; Dyk, J.S.; Beukes, N.; Pletschke, B.I. Synergy between EngE, XynA and ManA from Clostridium cellulovorans on corn stalk, grass and pineapple pulp substrates. 3 Biotech 2011, 1, 187-192. [CrossRef]

21. Malgas, S.; Pletschke, B.I. Combination of CTec2 and GH5 or GH26 endo-mannanases for effective lignocellulosic biomass degradation. Catalysts 2020, 10, 1193. [CrossRef]

22. Omwango, E.; Njagi, E.N.; Orinda, G.; Wanjau, R. Nutrient enrichment of pineapple waste using Aspergillus niger and Trichoderma viride by solid state fermentation. Afr. J. Biotechnol. 2013, 12, 6193-6196. [CrossRef]

23. Sukruansuwan, V.; Napathorn, S.C. Use of agro-industrial residue from the canned pineapple industry for polyhydroxybutyrate production by Cupriavidus necator strain A-04. Biotechnol. Biofuels 2018, 11, 202. [CrossRef]

24. Aruna, T.E. Production of value-added product from pineapple peels using solid state fermentation. Innov. Food Sci. Emerg. Technol. 2019, 57, 102193. [CrossRef]

25. Clauser, N.M.; Gutiérrez, S.; Area, M.C.; Felissia, F.E.; Vallejos, M.E. Techno-economic assessment of carboxylic acids, furfural, and pellet production in a pine sawdust biorefinery. Biofuels Bioprod. Biorefin. 2018, 12, 997-1012. [CrossRef]

26. Andrew, J.; Johakimu, J.; Lekha, P.; Gibril, M.; Sitholé, B. Beneficiation of sawdust waste in the context of an integrated forest biorefinery mill: Kraft and prehydrolysis kraft Pulping properties. In Opportunities for Biomass and Organic Waste Valorisation; Godfrey, L., Görgens, J.F., Roman, H., Eds.; Taylor \& Francis: Oxfordshire, UK, 2020; pp. 123-139.

27. Ferreira-Santos, P.; Zanuso, E.; Genisheva, Z.; Rocha, C.M.R.; Teixeira, J.A. Green and sustainable valorization of bioactive phenolic compounds from pinus by-products. Molecules 2020, 25, 2931. [CrossRef]

28. Rodríguez, E.R.; Martín, J.D.; Romero, C.D. Aloe vera as a functional ingredient in foods. Crit. Rev. Food Sci. Nutr. 2010, 50, 305-326. [CrossRef] [PubMed]

29. Tai-Nin Chow, J.; Williamson, D.A.; Yates, K.M.; Goux, W.J. Chemical characterization of the immunomodulating polysaccharide of Aloe vera L. Carbohydr. Res. 2005, 340, 1131-1142. [CrossRef] [PubMed]

30. Rodríguez-González, V.M.; Femenia, A.; González-Laredo, R.F.; Rocha-Guzmán, N.E.; Gallegos-Infante, J.A.; Candelas-Cadillo, M.G.; Ramírez-Baca, P.; Simal, S.; Rosselló, C. Effects of pasteurization on bioactive polysaccharide acemannan and cell wall polymers from Aloe barbadensis Miller. Carbohydr. Polym. 2011, 86, 1675-1683. [CrossRef]

31. Chang, X.L.; Chen, B.Y.; Feng, Y.M. Water-soluble polysaccharides isolated from skin juice, gel juice and flower of Aloe vera Miller. J. Taiwan Inst. Chem. Eng. 2011, 42, 197-203. [CrossRef]

32. Minjares-Fuentes, R.; Femenia, A.; Comas-Serra, F.; Rodríguez-González, V.M. Compositional and structural features of the main bioactive polysaccharides present in the aloe vera plant. J. AOAC Int. 2018, 101, 1711-1719. [CrossRef]

33. Simoes, J.; Nunes, F.M.; Coimbra, M.A.; Domingues, M.R. Mass spectrometry characterization of an Aloe vera mannan presenting immunostimulatory activity. Carbohydr. Res. 2012, 90, 229-236. [CrossRef] [PubMed] 
34. Wongsiridetchai, C.; Chiangkham, W.; Khlaihiran, N.; Sawangwan, T.; Wongwathanarat, P.; Charoenrat, T.; Chantorn, S. Alkaline pretreatment of spent coffee grounds for oligosaccharides production by mannanase from Bacillus sp. GA2(1). Agric. Nat. Resour. 2018, 52, 222-227. [CrossRef]

35. Ballesteros, L.F.; Cerqueira, M.A.; Teixeira, J.A.; Mussatto, S.I. Characterization of polysaccharides extracted from spent coffee grounds by alkali pretreatment. Carbohydr. Polym. 2015, 127, 347-354. [CrossRef] [PubMed]

36. Nguyen, Q.A.; Cho, E.J.; Lee, D.S.; Bae, H.J. Development of an advanced integrative process to create valuable biosugars including manno-oligosaccharides and mannose from spent coffee grounds. Bioresour. Technol. 2019, 272, 209-216. [CrossRef] [PubMed]

37. Simões, J.; Maricato, É.; Nunes, F.M.; Domingues, M.R.; Coimbra, M.A. Thermal stability of spent coffee ground polysaccharides: Galactomannans and arabinogalactans. Carbohydr. Polym. 2014, 101, 256-264. [CrossRef] [PubMed]

38. Favaro, C.P.; Baraldi, I.J.; Casciatori, F.P. $\beta$-Mannanase production using coffee industry waste for application in soluble coffee processing. Biomolecules 2020, 10, 227. [CrossRef]

39. Asano, I.; Umemura, M.; Fujii, S.; Hoshino, H.; Iino, H. Effects of mannooligosaccharides from coffee mannan on fecal microflora and defecation in healthy volunteers. Food Sci. Technol. Res. 2004, 10, 93-97. [CrossRef]

40. Gu, J.; Pei, W.; Tang, S.; Yan, F.; Peng, Z.; Huang, C.; Yang, J.; Yong, Q. Procuring biologically active galactomannans from spent coffee ground (SCG) by autohydrolysis and enzymatic hydrolysis. Int. J. Biol. Macromol. 2020, 149, 572-580. [CrossRef]

41. Abdeltawab, A.M.; Khattab, M.S.A. Utilization of palm kernel cake as a ruminant feed for animal: A review. Asian J. Biol. Sci. 2018, 11, 157-164. [CrossRef]

42. Sharmila, A.; Alimon, A.R.; Azhar, K.; Noor, H. Improving nutritional values of palm kernel cake (PKC) as poultry feeds: A review. Malays. J. Anim. Sci. 2014, 17, 1-18.

43. Aguzey, H.A.; Gao, Z.H.; Wu, H.H.; Cheng, G.L.; Wu, Z.M.; Chen, J.H.; Niu, Z.L. Enzymatic treatment of palm kernel cake improves intestinal health, gut microbiota and immune system of broilers. J. Anim. Plant Sci. 2020, 30, 517-526. [CrossRef]

44. Ariandi; Yopi; Meryandini, A. Enzymatic hydrolysis of copra meal by mannanase from Streptomyces sp. BF3.1 for the production of mannooligosaccharides. HAYATI J. Biosci. 2015, 22, 79-86. [CrossRef]

45. Kangas, H.; Felissia, F.E.; Filgueira, D.; Ehman, N.V.; Vallejos, M.E.; Imlauer, C.M.; Lahtinen, P.; Area, M.C.; Chinga-Carrasco, A.G. 3D printing high-consistency enzymatic nanocellulose obtained from a soda-ethanol-O2 pine sawdust pulp. Bioengineering 2019, 6, 60. [CrossRef] [PubMed]

46. Rättö, M.; Siika-aho, M.; Buchert, J.; Valkeajävi, A.; Viikari, L. Enzymatic hydrolosis of isolated and fibre-bound galactoglucomannans from pine-wood and pine kraft pulp. Appl. Microbiol. Biotechnol. 1993, 40, 449-454. [CrossRef]

47. Samanta, A.K.; Jayapal, N.; Jayaram, C.; Roy, S.; Kolte, A.P.; Senani, S.; Sridhar, M. Xylooligosaccharides as prebiotics from agricultural by-products: Production and applications. Bioact. Carbohydr. Diet. Fibre 2015, 5, 62-71. [CrossRef]

48. Malgas, S.; van Dyk, J.S.; Pletschke, B.I. A review of the enzymatic hydrolysis of mannans and synergistic interactions between $\beta$-mannanase, $\beta$-mannosidase and $\alpha$-galactosidase. World J. Microbiol. Biotechnol. 2015, 31, 1167-1175. [CrossRef] [PubMed]

49. Singh, S.; Singh, G.; Arya, S.K. Mannans: An overview of properties and application in food products. Int. J. Biol. Macromol. 2018, 119, 79-95. [CrossRef]

50. Dhawan, S.; Kaur, J. Microbial mannanases: An overview of production and applications. Crit. Rev. Biotechnol. 2007, 27, 197-216. [CrossRef] [PubMed]

51. Moreira, L.R.S.; Filho, E.X.F. An overview of mannan structure and mannan-degrading enzyme systems. Appl. Microbiol. Biotechnol. 2008, 79, 165-178. [CrossRef]

52. Malgas, S.; van Dyk, S.J.; Pletschke, B.I. $\beta$-Mannanase (Man26A) and $\alpha$-galactosidase (Aga27A) synergism-A key factor for the hydrolysis of galactomannan substrates. Enzym. Microb. Technol. 2015, 70, 1-8. [CrossRef]

53. Tailford, L.E.; Ducros, V.M.A.; Flint, J.E.; Roberts, S.M.; Morland, C.; Zechel, D.L.; Smith, N.; Bjørnvad, M.E.; Borchert, T.V.; Wilson, K.S.; et al. Understanding how diverse $\beta$-mannanases recognize heterogeneous substrates. Biochemistry 2009, 48, 7009-7018. [CrossRef] [PubMed]

54. Shallom, D.; Shoham, Y. Microbial hemicellulases. Curr. Opin. Microbiol. 2003, 6, 219-228. [CrossRef]

55. Shoseyov, O.; Shani, Z.; Levy, I. Carbohydrate binding modules: Biochemical properties and novel applications. Microbiol. Mol. Biol. Rev. 2006, 70, 283-295. [CrossRef]

56. Van Zyl, W.H.; Rose, S.H.; Trollope, K.; Görgens, J.F. Fungal $\beta$-mannanases: Mannan hydrolysis, heterologous production and biotechnological applications. Process Biochem. 2010, 45, 1203-1213. [CrossRef]

57. Ghosh, A.; Luís, A.S.; Brás, J.L.A.; Fontes, C.M.G.A.; Goyal, A. Thermostable recombinant $\beta$ - $(1 \rightarrow 4)$-mannanase from C. thermocellum: Biochemical characterization and manno-oligosaccharides production. J. Agric. Food Chem. 2013, 61, 12333-12344. [CrossRef] [PubMed]

58. Yamabhai, M.; Sak-Ubol, S.; Srila, W.; Haltrich, D. Mannan biotechnology: From biofuels to health. Crit. Rev. Biotechnol. 2016, 36, 30-42. [CrossRef]

59. Suzuki, K.; Michikawa, M.; Sato, H.; Yuki, M.; Kamino, K.; Ogasawara, W.; Fushinobu, S.; Kaneko, S. Purification, cloning, functional expression, structure, and characterization of a thermostable $\beta$-mannanase from Talaromyces trachyspermus B168 and its efficiency in production of mannooligosaccharides from coffee wastes. J. Appl. Glycosci. 2018, 65, 13-21. [CrossRef]

60. Kumar Suryawanshi, R.; Kango, N. Production of mannooligosaccharides from various mannans and evaluation of their prebiotic potential. Food Chem. 2021, 334, 127428. [CrossRef] 
61. Li, Y.; Yi, P.; Liu, J.; Yan, Q.; Jiang, Z. High-level expression of an engineered $\beta$-mannanase (mRmMan5A) in Pichia pastoris for manno-oligosaccharide production using steam explosion pretreated palm kernel cake. Bioresour. Technol. 2018, $256,30-37$. [CrossRef]

62. Bååth, J.A.; Abad, A.M.; Berglund, J.; Larsbrink, J.; Vilaplana, F.; Olsson, L. Mannanase hydrolysis of Spruce galactoglucomannan focusing on the influence of acetylation on enzymatic mannan degradation. Biotechnol. Biofuels 2018, 11, 114. [CrossRef]

63. Patel, S.; Goyal, A. Functional oligosaccharides: Production, properties and applications. World J. Microbiol. Biotechnol. 2011, 27, 1119-1128. [CrossRef]

64. Nimptsch, K.; Süß, R.; Riemer, T.; Nimptsch, A.; Schnabelrauch, M.; Schiller, J. Differently complex oligosaccharides can be easily identified by matrix-assisted laser desorption and ionization time-of-flight mass spectrometry directly from a standard thin-layer chromatography plate. J. Chromatogr. A 2010, 1217, 3711-3715. [CrossRef] [PubMed]

65. Bernardi, T.; Bortolini, O.; Massi, A.; Sacchetti, G.; Tacchini, M.; De Risi, C. Exploring the synergy between HPTLC and HPLC-DAD for the investigation of wine-making by-products. Molecules 2019, 24, 3416. [CrossRef] [PubMed]

66. Starr, C.M.; Masada, R.I.; Hague, C.; Skop, E.; Klock, J.C. Fluorophore-assisted carbohydrate electrophoresis in the separation, analysis, and sequencing of carbohydrates. J. Chromatogr. A 1996, 720, 295-321. [CrossRef]

67. O'Shea, M.G.; Samuel, M.S.; Konik, C.M.; Morell, M.K. Fluorophore-assisted carbohydrate electrophoresis (FACE) of oligosaccharides: Efficiency of labelling and high-resolution separation. Carbohydr. Res. 1998, 307, 1-12. [CrossRef]

68. Goins, T.L.; Cutler, J.I.M.E. Relative abundance of oligosaccharides in Candida species as determined by fluorophore-assisted carbohydrate electrophoresis. J. Clin. Microbiol. 2000, 38, 2862-2869. [CrossRef]

69. Srivastava, P.K.; Panwar, D.; Prashanth, K.V.H.; Kapoor, M. Structural characterization and in vitro fermentation of $\beta$ mannooligosaccharides produced from locust bean gum by GH-26 endo- $\beta-1,4-m a n n a n a s e ~(M a n B-1601)$. J. Agric. Food Chem. 2017, 65, 2827-2838. [CrossRef]

70. Kalidas, N.R.; Saminathan, M.; Ismail, I.S.; Abas, F.; Maity, P.; Islam, S.S.; Manshoor, N.; Shaari, K. Structural characterization and evaluation of prebiotic activity of oil palm kernel cake mannanoligosaccharides. Food Chem. 2017, 234, 348-355. [CrossRef]

71. Morrill, J.; Kulcinskaja, E.; Sulewska, A.M.; Lahtinen, S.; Stålbrand, H.; Svensson, B.; Abou Hachem, M. The GH5 1,4- $\beta$-mannanase from Bifidobacterium animalis subsp. lactis Bl-04 possesses a low-affinity mannan-binding module and highlights the diversity of mannanolytic enzymes Protein and enzyme biochemistry. BMC Biochem. 2015, 16, 26. [CrossRef]

72. Couturier, M.; Roussel, A.; Rosengren, A.; Leone, P.; Stålbrand, H.; Berrin, J.G. Structural and biochemical analyses of glycoside hydrolase families 5 and $26 \beta$-(1,4)-mannanases from Podospora anserina reveal differences upon manno-oligosaccharide catalysis. J. Biol. Chem. 2013, 288, 14624-14635. [CrossRef]

73. Liu, Z.; Ning, C.; Yuan, M.; Yang, S.; Wei, X.; Xiao, M.; Fu, X.; Zhu, C.; Mou, H. High-level expression of a thermophilic and acidophilic $\beta$-mannanase from Aspergillus kawachii IFO 4308 with significant potential in mannooligosaccharide preparation. Bioresour. Technol. 2020, 295, 122257. [CrossRef]

74. Aguilera-Gálvez, C.; Vásquez-Ospina, J.J.; Gutiérrez-Sanchez, P.; Acuña-Zornosa, R. Cloning and biochemical characterization of an endo-1,4- $\beta$-mannanase from the coffee berry borer Hypothenemus hampei. BMC Res. Notes 2013, 6, 333. [CrossRef]

75. Zang, H.; Xie, S.; Wu, H.; Wang, W.; Shao, X.; Wu, L.; Rajer, F.U.; Gao, X. A novel thermostable GH5_7 $\beta$-mannanase from Bacillus pumilus GBSW19 and its application in manno-oligosaccharides (MOS) production. Enzym. Microb. Technol. 2015, 78, 1-9. [CrossRef] [PubMed]

76. Harnpicharnchai, P.; Pinngoen, W.; Teanngam, W.; Sornlake, W.; Sae-Tang, K.; Manitchotpisit, P.; Tanapongpipat, S. Production of high activity Aspergillus niger BCC4525 $\beta$-mannanase in Pichia pastoris and its application for mannooligosaccharides production from biomass hydrolysis. Biosci. Biotechnol. Biochem. 2016, 80, 2298-2305. [CrossRef] [PubMed]

77. Arunrattanamook, N.; Wansuksri, R.; Uengwetwanit, T.; Champreda, V. Engineering of $\beta$-mannanase from Aspergillus niger to increase product selectivity towards medium chain length mannooligosaccharides. J. Biosci. Bioeng. 2020, 130, 443-449. [CrossRef] [PubMed]

78. Chauhan, P.S.; Sharma, P.; Puri, N.; Gupta, N. Purification and characterization of an alkali-thermostable $\beta$-mannanase from Bacillus nealsonii PN-11 and its application in mannooligosaccharides preparation having prebiotic potential. Eur. Food Res. Technol. 2014, 238, 927-936. [CrossRef]

79. Chauhan, P.S.; Sharma, P.; Puri, N.; Gupta, N. A process for reduction in viscosity of coffee extract by enzymatic hydrolysis of mannan. Bioprocess Biosyst. Eng. 2014, 37, 1459-1467. [CrossRef]

80. Zhang, R.; Li, X.Y.; Cen, X.L.; Gao, Q.H.; Zhang, M.; Li, K.Y.; Wu, Q.; Mu, Y.L.; Tang, X.H.; Zhou, J.P.; et al. Enzymatic preparation of manno-oligosaccharides from locust bean gum and palm kernel cake, and investigations into its prebiotic activity. Electron. J. Biotechnol. 2021, 49, 64-71. [CrossRef]

81. Bågenholm, V.; Wiemann, M.; Reddy, S.K.; Bhattacharya, A.; Logan, D.T.; Stålbrand, H. A surface exposed GH26 $\beta$-mannanase from Bacteroides ovatus: Structure, role and phylogenetic analysis of BoMan26B. J. Biol. Chem. 2019, 294, 9100-9117. [CrossRef]

82. Piwpankaew, Y.; Sakulsirirat, S.; Nitisinprasert, S.; Nguyen, T.H.; Haltrich, D.; Keawsompong, S. Cloning, secretory expression and characterization of recombinant $\beta$-mannanase from Bacillus circulans NT 6.7. Springerplus 2014, 3, 430. [CrossRef]

83. Bågenholm, V.; Reddy, S.K.; Bouraoui, H.; Morrill, J.; Kulcinskaja, E.; Bahr, C.M.; Aurelius, O.; Rogers, T.; Xiao, Y.; Logan, D.T.; et al. Galactomannan catabolism conferred by a polysaccharide utilisation locus of Bacteroides ovatus: Enzyme synergy and crystal structure of a $\beta$-mannanase. J. Biol. Chem. 2017, 292, 229-243. [CrossRef] [PubMed] 
84. Cartmell, A.; Topakas, E.; Ducros, V.M.A.; Suits, M.D.L.; Davies, G.J.; Gilbert, H.J. The Cellvibrio japonicus mannanase CjMan26C displays a unique exo-mode of action that is conferred by subtle changes to the distal region of the active site. J. Biol. Chem. 2008, 283, 34403-34413. [CrossRef]

85. Tsukagoshi, H.; Nakamura, A.; Ishida, T.; Otagiri, M.; Moriya, S.; Samejima, M.; Igarashi, K.; Kitamoto, K.; Arioka, M. The GH26 $\beta$-mannanase RsMan26H from a symbiotic protist of the termite Reticulitermes speratus is an endo-processive mannobiohydrolase: Heterologous expression and characterization. Biochem. Biophys. Res. Commun. 2014, 452, 520-525. [CrossRef] [PubMed]

86. Zhang, Y.; Ju, J.; Peng, H.; Gao, F.; Zhou, C.; Zeng, Y.; Xue, Y.; Li, Y.; Henrissat, B.; Gao, G.F.; et al. Biochemical and structural characterization of the intracellular mannanase AaManA of Alicyclobacillus acidocaldarius reveals a novel glycoside hydrolase family belonging to clan GH-A. J. Biol. Chem. 2008, 283, 31551-31558. [CrossRef]

87. Liu, W.; Ma, C.; Liu, W.; Zheng, Y.; Chen, C.-C.; Liang, A.; Luo, X.; Li, Z.; Ma, W.; Song, Y.; et al. Functional and structural investigation of a novel $\beta$-mannanase BaMan113A from Bacillus sp. N16-5. Int. J. Biol. Macromol. 2021, 182, 899-909. [CrossRef]

88. Shimizu, M.; Kaneko, Y.; Ishihara, S.; Mochizuki, M.; Sakai, K.; Yamada, M.; Murata, S.; Itoh, E.; Yamamoto, T.; Sugimura, Y.; et al. Novel $\beta$-1,4-mannanase belonging to a new glycoside hydrolase family in Aspergillus nidulans. J. Biol. Chem. 2015, 290, 27914-27927. [CrossRef]

89. Jana, U.K.; Suryawanshi, R.K.; Prajapati, B.P.; Soni, H.; Kango, N. Production optimization and characterization of mannooligosaccharide generating $\beta$-mannanase from Aspergillus oryzae. Bioresour. Technol. 2018, 268, 308-314. [CrossRef] [PubMed]

90. Jana, U.K.; Kango, N. Characteristics and bioactive properties of mannooligosaccharides derived from agro-waste mannans. Int. J. Biol. Macromol. 2020, 149, 931-940. [CrossRef]

91. Purnawan, A.; Yopi, Y.; Irawadi, T.T. Production of manooligomannan from palm kernel cake by mannanase produced from Streptomyces cyaenus. Biosaintifika J. Biol. Biol. Educ. 2017, 9, 73-80. [CrossRef]

92. Pangestu, R.; Rahmani, N.; Palar, R.; Lisdiyanti, P. Yopi The effect of biomass particle size and chemical structure on the enzymatic hydrolysis reaction of galactomannan from sugar palm fruit by $\beta$-mannanase from Kitasatospora sp. KY576672. IOP Conf. Ser. Earth Environ. Sci. 2019, 251, 012008. [CrossRef]

93. Yopi; Rahmani, N.; Amanah, S.; Santoso, P.; Lisdiyanti, P. The production of $\beta$-mannanase from Kitasatospora sp. strain using submerged fermentation: Purification, characterization and its potential in mannooligosaccharides production. Biocatal. Agric. Biotechnol. 2020, 24, 101532. [CrossRef]

94. Bangoria, P.; Divecha, J.; Shah, A. Production of mannooligosaccharides producing b-mannanase by newly isolated Penicillium aculeatum APS1 using oil seed residues under solid state fermentation. Biocatal. Agric. Biotechnol. 2021, 34, 102023. [CrossRef]

95. Chacher, M.F.A.; Kamran, Z.; Ahsan, U.; Ahmad, S.; Koutoulis, K.C.; Qutab Ud DIn, H.G.; Cengiz, O. Use of mannan oligosaccharide in broiler diets: An overview of underlying mechanisms. Worlds. Poult. Sci. J. 2017, 73, 831-844. [CrossRef]

96. Baurhoo, B.; Letellier, A.; Zhao, X.; Ruiz-Feria, C. Cecal populations of Lactobacilli and Bifidobacteria and Escherichia coli populations after in vivo Escherichia coli challenge in birds fed diets with purified lignin or mannanoligoccharides. Poult. Sci. 2007, 86, 2509-2516.

97. Bland, E.J.; Keshavarz, T.; Bucke, C. The influence of small oligosaccharides on the immune system. Carbohydr. Res. 2004, 339, 1673-1678. [CrossRef]

98. Saeed, M.; Ahmad, F.; Arain, M.A.; Abd El-Hack, M.E.; Emam, M.; Bhutto, Z.A.; Moshaveri, A. Use of mannan-oligosaccharides (MOS) as a feed additive in poultry nutrition. J. World's Poult. Res. 2017, 7, 94-103.

99. Turner, M.W. The role of mannose-binding lectin in health and disease. Mol. Immunol. 2003, 40, 423-429. [CrossRef]

100. Birben, E.; Sahiner, U.M.; Sackesen, C.; Erzurum, S.; Kalayci, O. Oxidative stress and antioxidant defense. World Allergy Organ. J. 2012, 5, 9-19. [CrossRef]

101. Ismail, S.A.; Hassan, A.A.; Emran, M.A. Economic production of thermo-active endo $\beta$-mannanase for the removal of food stain and production of antioxidant manno-oligosaccharides. Biocatal. Agric. Biotechnol. 2019, 22, 101387. [CrossRef]

102. Thambiraj, S.R.; Phillips, M.; Koyyalamudi, S.R.; Reddy, N. Yellow lupin (Lupinus luteus L.) polysaccharides: Antioxidant, immunomodulatory and prebiotic activities and their structural characterisation. Food Chem. 2018, 267, 319-328. [CrossRef]

103. Aliakbarlu, J.; Mohammadi, S.; Khalili, S. A study on antioxidant potency and antibacterial activity of water extracts of some spices widely consumed in Iranian diet. J. Food Biochem. 2014, 38, 159-166. [CrossRef]

104. Pereira, D.I.A.; Gibson, G.R. Effects of consumption of probiotics and prebiotics on serum lipid levels in humans. Crit. Rev. Biochem. Mol. Biol. 2002, 37, 259-281. [CrossRef] [PubMed]

105. Van Loo, J.; Cummings, J.; Delzenne, N.; Englyst, H.; Franck, A.; Hopkins, M.; Kok, N.; Macfarlane, G.; Newton, D.; Quigley, M.; et al. Functional food properties of non-digestible oligosaccharides: A consensus report from the ENDO project (DGXII AIRII-CT94-1095). Br. J. Nutr. 1999, 81, 121-132. [CrossRef] [PubMed]

106. Lee, A.; Lim, W.; Kim, S.; Khil, H.; Cheon, E.; An, S.; Hong, S.; Lee, D.H.; Kang, S.; Oh, H.; et al. Coffee Intake and Obesity: A Meta-Analysis. Nutrients 2019, 11, 1274. [CrossRef] [PubMed]

107. Maki, C.; Funakoshi-Tago, M.; Aoyagi, R.; Ueda, F.; Kimura, M.; Kobata, K.; Tago, K.; Tamura, H. Coffee extract inhibits adipogenesis in 3T3-L1 preadipocyes by interrupting insulin signaling through the downregulation of IRS1. PLoS ONE 2017, 12, e0173264. [CrossRef]

108. Van Dam, R.M.; Feskens, E.J.M. Coffee consumption and risk of type 2 diabetes mellitus. Lancet 2002, 360, 1477-1478. [CrossRef] 
109. Ghosh, A.; Verma, A.K.; Tingirikari, J.R.; Shukla, R.; Goyal, A. Recovery and purification of oligosaccharides from copra meal by recombinant endo- $\beta$-mannanase and deciphering molecular mechanism involved and its role as potent therapeutic agent. Mol. Biotechnol. 2014, 57, 111-127. [CrossRef]

110. Li, T.; Yan, Q.; Wen, Y.; Liu, J.; Sun, J.; Jiang, Z. Synbiotic yogurt containing konjac mannan oligosaccharides and Bifidobacterium animalis ssp. lactis BB12 alleviates constipation in mice by modulating the stem cell factor (SCF)/c-Kit pathway and gut microbiota. J. Dairy Sci. 2021, 104, 5239-5255. [CrossRef] 